\title{
Effect of zinc supplementation on serum zinc and calcium levels in postmenopausal osteoporotic women in Tabriz, Islamic Republic of Iran
}

Marjan Mahdaviroshan, ${ }^{1}$ M. Golzarand, ${ }^{2}$ M. Rahbar Taramsari ${ }^{3}$ and Merhan Mahdaviroshan ${ }^{3}$

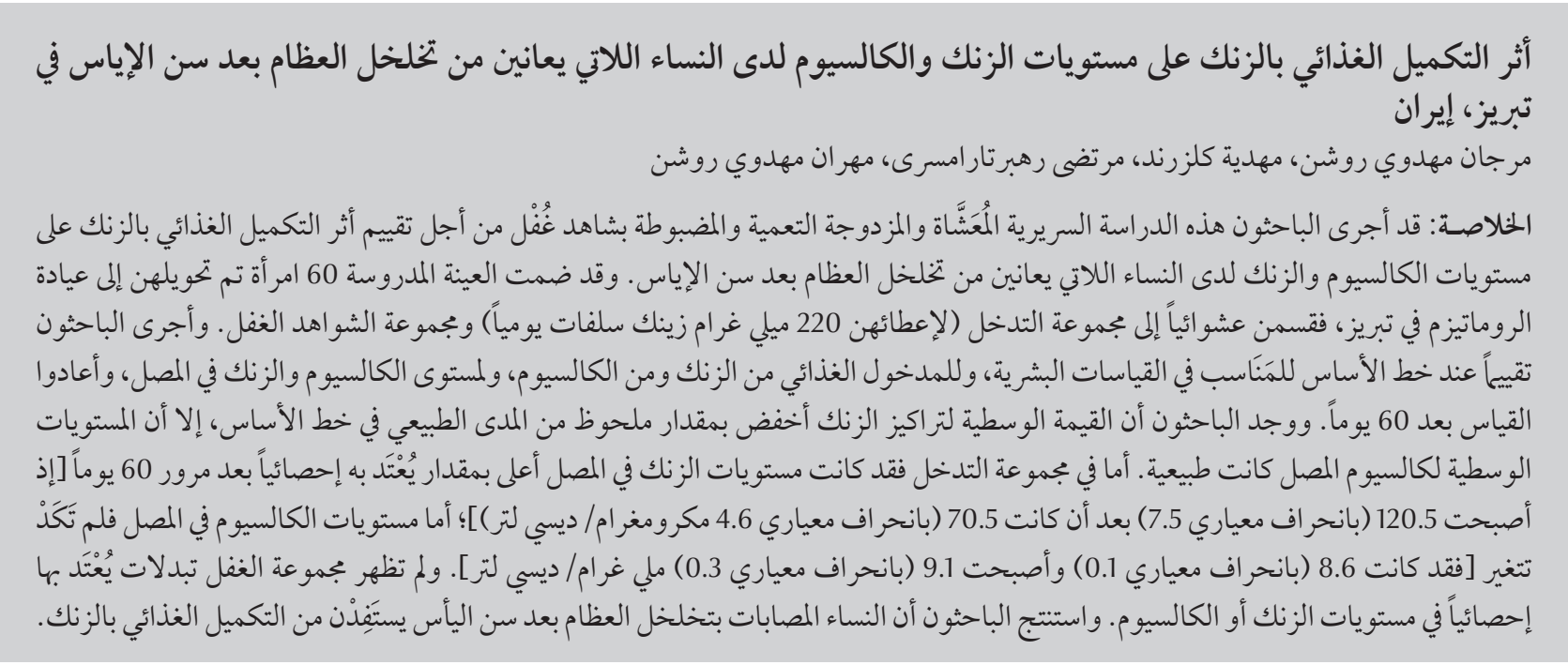

ABSTRACT Research on the zinc status of osteoporotic women is scarce. This randomized, double-blind, placebocontrolled clinical trial assessed the effect of zinc supplementation on serum zinc and calcium levels in postmenopausal osteoporotic women. A sample of 60 women referred to a rheumatology clinic in Tabriz were randomly divided into intervention (220 mg zinc sulfate daily) and placebo groups. Anthropometric indices, dietary intake of zinc and calcium and serum zinc and calcium were assessed at baseline and after 60 days. Mean serum zinc concentrations were markedly lower than the normal range at baseline, but mean serum calcium levels were normal. In the intervention group serum zinc levels were significantly higher after 60 days [120.5 (SD 7.5) versus 70.5 (SD 4.6) $\mu \mathrm{g} / \mathrm{dL}]$ while serum calcium levels were unchanged [8.6 (SD 0.1) versus 9.1 (SD 0.3) mg/dL]. The placebo group showed no significant changes in zinc or calcium levels. Postmenopausal osteoporotic women may benefit from zinc supplementation.

Effet de la supplémentation en zinc sur les taux de zinc et de calcium sériques chez les femmes ostéoporotiques ménopausées à Tabriz (République islamique d'Iran)

RÉSUMÉ Le présent essai clinique randomisé, en double aveugle, contrôlé contre placebo, a évalué l'effet de la supplémentation en zinc sur les taux de zinc et de calcium sériques chez des femmes ostéoporotiques ménopausées. Un échantillon de 60 femmes orientées vers une clinique de rhumatologie de Tabriz a été randomisé, soit dans un groupe bénéficiant d'une intervention (220 mg de sulfate de zinc par jour), soit dans un groupe sous placebo. Les mesures anthropométriques, l'apport alimentaire en zinc et en calcium, les taux de zinc et de calcium sériques ont été évalués au début de l'étude puis à 60 jours. Les concentrations moyennes initiales en zinc sérique étaient nettement inférieures aux valeurs normales, mais les taux de calcium sérique moyens étaient normaux. Dans le groupe bénéficiant de l'intervention, les taux de zinc sérique étaient nettement supérieurs à 60 jours (120,5 $\mu \mathrm{g} / \mathrm{dl}$ [ET $7,5]$ contre $70,5 \mu \mathrm{g} / \mathrm{dl}$ [ET 4,6]) tandis que les taux de calcium sérique sont restés stables $(8,6 \mathrm{mg} / \mathrm{dl}$ [ET 0,1] contre $9,1 \mathrm{mg} / \mathrm{dl}$ [ET 0,3]). Les taux de zinc et de calcium n'ont pas beaucoup évolué dans le groupe sous placebo. La supplémentation en zinc peut être bénéfique aux femmes ostéoporotiques ménopausées.

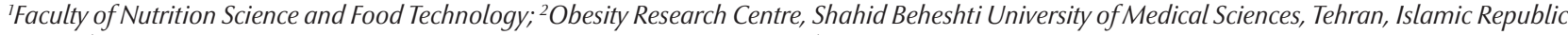
of Iran (Correspondence to M. Golzarand: mahdieh_golzarand@yahoo.com). ${ }^{3}$ Guilan University of Medical Sciences, Guilan, Islamic Republic of Iran. Received: 03/10/11; accepted: 21/02/12 


\section{Introduction}

Osteoporosis, characterized by decreased bone mass, seems to be due to an imbalance between bone resorption and bone formation at older ages $[1-3]$ and is widely recognized as a major public health problem, especially for women [4]. The etiology of osteoporosis is multi-factorial. Many factors-genetic differences, endocrine factors and lifestyle behaviour, such as physical activity and diet, especially calcium and zinc intake-are thought to play a role in osteoporosis and its prevention [5].

Zinc has been demonstrated to have a wide variety of roles in mammalian systems and may play a physiological role in mineralization of bone tissue [6]. However, zinc nutritional deficiency is a global health problem. It has been estimated that almost half the world's population, especially those in developing countries, do not get sufficient zinc from their food $[7,8]$. Hill et al. showed a relationship between zinc nutritive status and bone turnover in elder adults [9]. In addition, zinc is required for the complete physiological action of vitamin D on calcium metabolism in rats [10]. A significant positive correlation between bone zinc content and bone strength suggests that zinc may play an important role in bone health [11]. It has been shown that the most definitive test for the diagnosis of zinc deficiency is a clinical response to therapeutic trial of zinc supplementation. Zinc concentrations in bone are greatly reduced during zinc deficiency [12].

There has been little research on the relationship of zinc intake and serum calcium and zinc levels in osteoporotic women, and experiments on the effect of calcium and zinc have been limited to animal studies. This study aimed to examine the effect of zinc supplementation on serum zinc and calcium concentrations in postmenopausal osteoporotic women.

\section{Methods}

\section{Study design and sample}

This was a randomized, double-blind, placebo controlled clinical trial, conducted on 60 postmenopausal osteoporotic women aged between $48-89$ years who were referred to the rheumatology clinic in Tabriz, Islamic Republic of Iran from January 2011 to March 2011. The sample size was designed to detect a $25 \mu \mathrm{g} / \mathrm{dL}$ difference among groups in serum zinc with $95 \%$ confidence interval (CI) and $90 \%$ power; the sample size, allowing for possible dropouts, was calculated as 30 patients in each group.

The inclusion criteria were having no history of hormone replacement therapy, bone disease, kidney stones, endocrine disorders, or any other medical conditions that could influence zinc status. Approval for the study was obtained from the regional medical research ethics committee in Tabriz University of Medical Sciences and informed consent was obtained from all the participants.

\section{Data collection}

At baseline, osteoporosis identification was performed by bone mineral density measurements in hip and spinal column using dual-energy X-ray absorptiometry and osteoporosis was defined as a Tscore $\leq-2.5$ standard deviations (SD).

The height and weight of the women was measured while they wore light clothes and without shoes, and body mass index (BMI) was calculated. In addition, 3-day 24-hour food recall of subjects, including 2 weekdays and 1 weekend day, were collected at baseline and after 60 days to estimate dietary intake of calcium and zinc [13]. The cut-offs for adequate intake of zinc and calcium was defined as $8-40 \mathrm{mg} / \mathrm{dL}$ and $1000-2000 \mathrm{mg} / \mathrm{dL}$, respectively [14].

Blood samples were collected from the arm in the afternoon and centrifuged within $2 \mathrm{~h}$ at $3000 \times \mathrm{g}$ for $10 \mathrm{~min}$. The serum was separated and stored at $-32{ }^{\circ} \mathrm{C}$ and serum calcium level was assessed using kits (Pars Azmoon Inc.). The cut-off range for normal values of serum calcium was $9.0-11.0 \mathrm{mg} / \mathrm{dL}$ and serum calcium concentrations $<9.0 \mathrm{mg} / \mathrm{dL}$ were considered as abnormal [15]. Serum zinc was analysed using atomic absorption spectrophotometer (Chemtech Analytical CTA 2000). The cut-off range for normal values of serum zinc was $100-140 \mu \mathrm{g} / \mathrm{dL}$ and serum zinc concentrations $<100 \mu \mathrm{g} / \mathrm{dL}$ were considered as abnormal [15].

Patients were randomly divided into 2 groups, an intervention group $(n$ $=30$ ) receiving 1 capsule of zinc sulfate $220 \mathrm{mg}$ (containing $50 \mathrm{mg}$ elemental zinc) each day, and a placebo group $(n=30)$ receiving a placebo containing starch. Patients were contacted every week to evaluate compliance to the intervention and to enquire about possible side-effects such as allergic reactions. After 60 days of intervention, dietary intake, anthropometric data and serum zinc and calcium levels were assessed again.

\section{Data analysis}

The data was analysed by SPSS, version 11.5, using Pearson correlation coefficients, independent $t$-test, paired $t$ test and 1 -sample $t$-test. $P$-values $<0.05$ were considered to indicate statistically significant differences.

\section{Results}

The mean age of the participants was 58.2 (SD 1.2) years and the mean age of menopause was 48.6 (SD 0.3) years. Mean weight was 68.0 (SD 1.0) kg and mean height was $156.8($ SD 0.8$) \mathrm{cm}$. As shown in Table 1, there were no significant differences in age, weight, height, BMI and age of menopause between the 2 groups at baseline. The results also showed that there were 
no significant differences in dietary calcium and zinc intake between the 2 groups at baseline and were significantly lower than the dietary reference intake (Table 1). The mean serum zinc concentration in the total group was markedly lower than the normal range $[67.1(\mathrm{SD} 3.8) \mu \mathrm{g} / \mathrm{dL}]$, while the mean serum calcium concentration was within the normal range [9.2 (SD $0.1) \mathrm{mg} / \mathrm{dL}]$.

There were no significant changes in anthropometric data and nutrient intake before and after 60 days in either the intervention or control groups ( $\mathrm{Ta}-$ ble 1)

There were no significant differences in calcium and zinc concentrations at baseline between the 2 groups (Figures 1 and 2). After 60 days, the group receiving zinc sulfate supplements had a significantly higher serum zinc concentration than at baseline [120.5 (SD 7.5) versus 70.5 (SD 4.6) $\mu \mathrm{g} / \mathrm{dL}](P<0.05)$ (Figure 1) but no significant difference in serum calcium concentration [8.6 (SD 0.1) versus 9.1 (SD 0.3) mg/dL] (Figure 2). No significant differences were found in calcium and zinc concentrations in the placebo group before and after the intervention.

\section{Discussion}

The results of this study demonstrated that serum zinc concentration in these osteoporotic women was significantly lower than the normal range (100-140 $\mu \mathrm{g} / \mathrm{dL}$ ), which is similar to the results obtained from the second National Health and Nutrition Interview Survey in 1976-80 [16], and an epidemiological survey conducted in Rome [17]. Although the results obtained suggested that low serum zinc concentrations may have been a result of low zinc dietary intake, Relea et al. [18] and Herzberg et al. [19] reported that urinary zinc excretion was higher in osteoporotic women.

\begin{tabular}{|c|c|c|}
\hline \multirow[t]{2}{*}{ Variable } & $\begin{array}{l}\text { Intervention group } \\
\qquad(n=30)\end{array}$ & $\begin{array}{l}\text { Placebo group }^{a} \\
\qquad(n=30)\end{array}$ \\
\hline & Mean (SD) & Mean (SD) \\
\hline Age (years) & $59.5(1.9)$ & $56.6(1.5)$ \\
\hline Menopausal age (years) & $48.5(0.6)$ & $48.8(0.4)$ \\
\hline \multicolumn{3}{|l|}{ Height $(\mathrm{cm})$} \\
\hline Baseline & $155.8(1.1)$ & $157.8(1.1)$ \\
\hline After 60 days & $155.6(1.2)$ & $157.8(1.0)$ \\
\hline \multicolumn{3}{|l|}{ Weight (kg) } \\
\hline Baseline & $68.3(1.6)$ & $67.7(1.6)$ \\
\hline After 60 days & $68.8(1.6)$ & $67.3(1.7)$ \\
\hline \multicolumn{3}{|l|}{$B M I\left(k g / m^{2}\right)$} \\
\hline Baseline & $28.1(0.6)$ & $27.2(0.5)$ \\
\hline After 60 days & $28.3(0.6)$ & $27.0(0.6)$ \\
\hline \multicolumn{3}{|l|}{ Zinc intake (mg/dL) } \\
\hline Baseline & $3.8(0.3)$ & $3.8(0.3)$ \\
\hline After 60 days & $3.6(0.2)$ & $3.8(0.3)$ \\
\hline \multicolumn{3}{|l|}{ Calcium intake $(\mathrm{mg} / \mathrm{dL})$} \\
\hline Baseline & $731.4(60.4)$ & $748.7(59.1)$ \\
\hline After 60 days & $723.0(59.3)$ & $731.5(54.9)$ \\
\hline
\end{tabular}

a $P>0.05$ versus intervention group (t-test) for all variables. $S D=$ standard deviation .

Our results showed a significant elevation of serum zinc concentration after 60 days of zinc supplementation. Clark et al., studying 47 peri-pubertal girls,

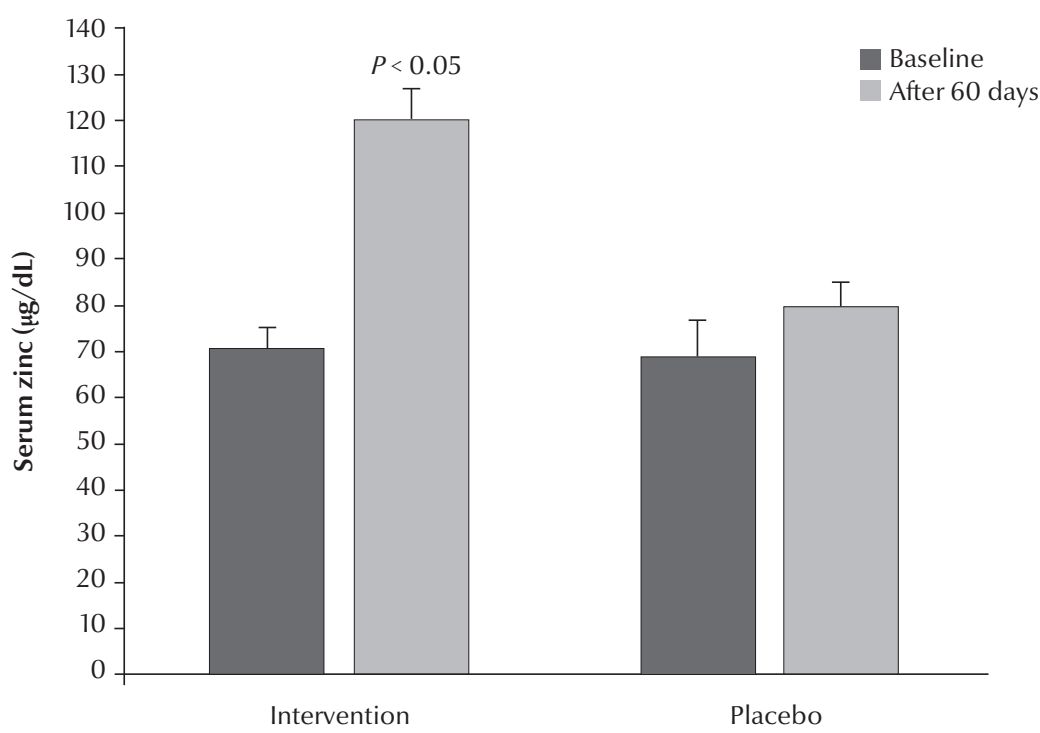

Figure 1 Effect of zinc sulfate on serum zinc concentration in postmenopausal osteoporotic women at baseline and after 60 days: intervention group $(n=30)$; placebo group $(n=30)$ showed that zinc supplementation for 6 weeks increased serum zinc levels [20], and Igarash et al. demonstrated that zinc supplementation for 28 days in rats with 


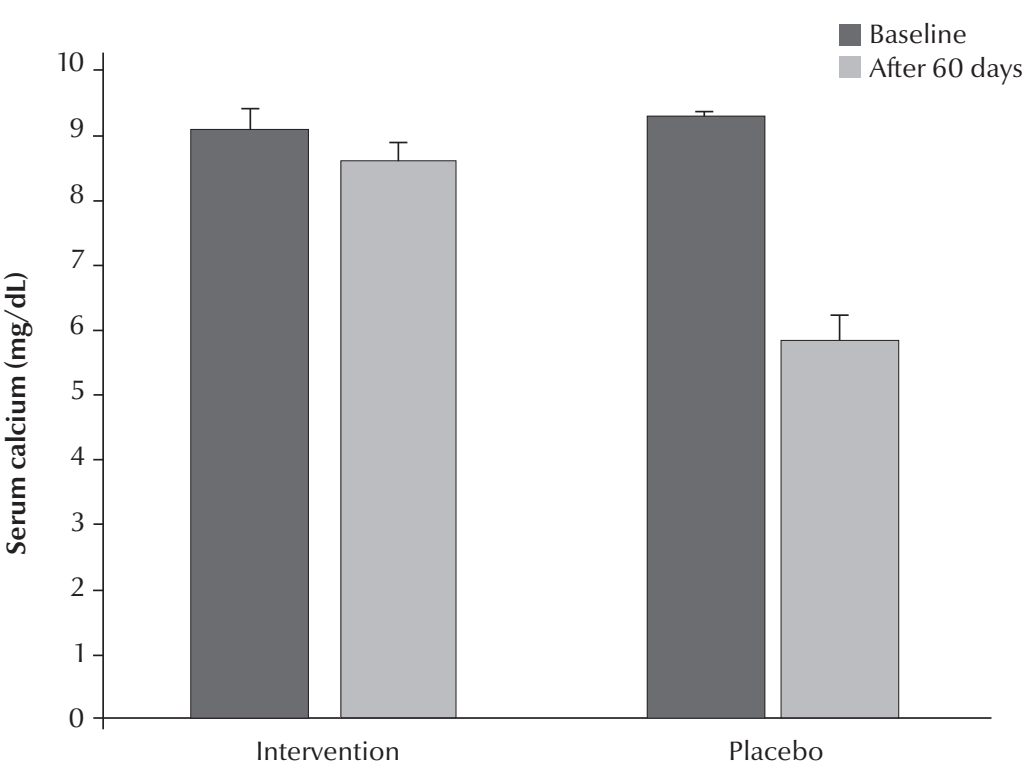

Figure 2 Effect of zinc sulfate on serum calcium concentration in postmenopausal osteoporotic women at baseline and after 60 days: intervention group $(n=30)$; placebo group $(n=30)$

zinc deficiency resulted in an elevation in serum zinc concentrations [21]. In addition, Sadighi et al. in a study on 60 patients with bone fracture showed that using 60 days of zinc supplementation caused a significant elevation of serum zinc $[22]$.

The association between dietary zinc intake and serum zinc in this study is concordant with the results of Taisun et al. [23] and Neggers et al. [24]. In addition, Taisun et al. demonstrated that plasma zinc was correlated with total zinc intake, including supplementary intake together with dietary zinc intake [23].

In this survey, the results showed no significant decreases in serum calcium concentrations after 60 days of zinc supplementation. Sunar et al. in a study on 40 adult female rats showed that zinc deficiency caused a significant decrease in calcium and phosphorus levels and that zinc supplementation $(3 \mathrm{mg} / \mathrm{kg} /$ day zinc sulfate intraperitoneal injection for 6 weeks) had a preventive effect on these changes in ovariectomized rats [25]. Few studies have focused on the interaction between calcium and zinc in humans and most studies on the subject are limited to animal studies [22-26]. The current study also showed no significant effect of zinc on calcium levels, and it therefore seems that further studies are needed to evaluate the role of zinc and its mechanism on serum calcium concentration.

\section{Conclusion}

This study demonstrated zinc deficiency in a group of postmenopausal osteoporotic women and that 60 days of zinc supplementation had a beneficial effect on zinc levels. Further studies are needed to evaluate the role of zinc on bone mineral density in humans.

\section{References}

1. Nishimoto SK et al. The effect of aging on bone formation in rats: biochemical and histological evidence for decreased bone formation capacity. Calcified Tissue International, 1985, 37:617-624.

2. Schapira D et al. Calcium and vitamin D enriched diets increase and preserve vertebral mineral content in aging laboratory rats. Bone, 1995, 16:575-582.

3. Wild RA et al. Declining adrenal androgens: an association with bone loss in aging women. Proceedings of the Society for Experimental Biology and Medicine, 1987, 186:355-360.

4. Zhong J, Igarashi A. Enhancing effect of zinc and vitamin K2 on bone components in the femoral tissue of female elderly rats. Journal of Health Science, 2001, 47:40-45.

5. Chee WS et al. Dietary calcium intake in postmenopausal Malaysian women: comparison between the food frequency questionnaire and three-day food records. Asia Pacific Journal of Clinical Nutrition, 2002, 11:142-146.

6. Cashman K, Flynn A. Trace elements and bone metabolism. Bibliotheca Nutritio et Dieta, 1998, 54:150-164.

7. Sian $\mathrm{L}$ et al. Zinc homeostasis during lactation in a population with a low zinc intake. American Journal of Clinical Nutrition, 2002, 75:99-103.
8. Osendarp SJ, West CE, Black RE; Maternal Zinc Supplementation Study Group. The need for maternal zinc supplementation in developing countries: an unresolved issue. Journal of Nutrition, 2003, 133:817S-827S.

9. Hill $\mathrm{T}$ et al. The relationship between the zinc nutritive status and biochemical marker of bone turnover in older European adult: the ZENITH study. European Journal of Clinical Nutrition, 2005, 59:S73-S78.

10. Zhang YH et al. [Effects of zinc deficiency on bone mineralization and its mechanism in rats]. Zhaong Fang Yi Xue Zhi, 2003, 37:121-124 [in Chinese].

11. Hambidge M. Biomarkers of trace mineral intake and status. Journal of Nutrition, 2003, 133(Suppl. 3):948S-955S.

12. Calhoun NR, Smith JC Jr, Becker KL. The role of zinc in bone metabolism. Clinical Orthopaedics and Related Research, 1974, 103:212-234.

13. Golzarand $\mathrm{M}$ et al. Association between modifiable lifestyle factors and inflammatory markers in patients with metabolic syndrome. Eastern Mediterranean Health Journal, 2012, 7:735-741.

14. Mahan LK, Scott-Stump S, Raymond JL, eds. Krause's food and the nutrition care process. Philadelphia, Saunders, 2012. 
15. Pagana KD, Pagana TJ, eds. Mosby's manual of diagnostic and laboratory tests. Philadelphia, Mosby, 2002.

16. Hotz C, Peerson JM, Brown KH. Suggested lower cutoffs of serum zinc concentrations for assessing zinc status: reanalysis of the second National Health and Nutrition Examination Survey data (1976-1980). American Journal of Clinical Nutrition, 2003, 78:756-764.

17. Hyun TH, Barrett-Connor E, Milne DB. Zinc intakes and plasma concentrations in men with osteoporosis: the Rancho Bernardo Study. American Journal of Clinical Nutrition, 2004, 80:715-721.

18. Relea P et al. Zinc, biochemical markers of nutrition, and type I osteoporosis. Age and Ageing, 1995, 24:303-307.

19. Herzberg $M$ et al. Zinc excretion in osteoporotic women. Journal of Bone and Mineral Research, 1990, 5:251-257.

20. Clark PJ, Eastell R, Barker ME. Zinc supplementation and bone growth in pubertal girls. Lancet, 1999, 354:485-486.

21. Igarash A, Yamaguchi M. Great increase in bone $66 \mathrm{KDa}$ protein and osteocalcin at later stage with healing rat fractures: Effect of zinc treatment. International Journal of Molecular Medicine, 2002, 11:223-228.
22. Sadighi A et al. The effects of zinc supplementation on serum zinc, alkaline phosphatase activity and fracture healing of bones. Saudi Medical Journal, 2008, 29:1276-1279.

23. Hyun TH, Barrett-Connor E, Milne DB. Zinc intakes and plasma concentrations in men with osteoporosis: the Rancho Bernardo Study. American Journal of Clinical Nutrition, 2004, 80:715-721.

24. Neggers YH et al. Plasma and erythrocyte zinc concentrations and their relationship to dietary zinc intake and zinc supplementation during pregnancy in low-income African-American women. Journal of the American Dietetic Association, 1998, 97:1269-1274.

25. Sunar $F$ et al. Zinc deficiency and supplementation in ovariectomized rats: their effect on serum estrogen and progesterone levels and their relation to calcium and phosphorus. Pakistan Journal of Pharmaceutical Sciences, 2009, 22:150-154.

26. Lönnerdal B. Dietary factors influencing zinc absorption. Journal of Nutrition, 2000, 130 (Suppl.):S1378-S1383. 